\title{
Energy coefficients of plant foods for broiler chickens at different ages ${ }^{1}$
}

\section{Coeficientes energéticos de alimentos de origem vegetal determinados com frangos de corte em diferentes idades}

\author{
José Luiz Schneiders²; Ricardo Vianna Nunes ${ }^{3}$; \\ Rodrigo André Schöne²; Rafael Frank2; Thaís Lorana Savoldi4; \\ Cláudio Yuji Tsutsumi ${ }^{3}$; Carina Scherer ${ }^{5}$; Leandro Dalcin Castilha ${ }^{4 *}$
}

\begin{abstract}
In order to determine the apparent metabolizable energy (AME), the AME corrected for nitrogen balance (AMEn), the apparent coefficients of metabolization (ACM) of gross energy and the ACM corrected for nitrogen balance (ACMn), an experiment was conducted to evaluate five different plant foods (corn, soybean meal, deactivated full-fat soybean, wheat bran and soybean oil) for broilers at different ages (1-8, 11-18, 21-28, 31-38 and 41-48 days). The method of total excreta collection was used, divided into five metabolism assays. The birds were housed in metabolic cages in a completely randomized design, with five treatments and five replicates per treatment, totaling 25 experimental units. The AME and AMEn values increased with the age of the birds for most foods, except soybean meal. The smaller $\mathrm{AMC}$ and $\mathrm{AMCn}$ of gross energy were obtained for wheat bran. There was adjustment of the equation to the linear response plateau model for the ACM of corn, soybean meal and deactivated full-fat soybean. The wheat bran and soybean oil were adjusted to the linear regression model. The equations show that the digestibility of energy tends to increase with age, except for soybean meal, which had higher metabolization with younger birds. We conclude that the age of the birds influences the determination of the metabolizable energy of feed.
\end{abstract}

Key words: Feed. Metabolism assay. Metabolizable energy. Poultry farming. Total collection.

\section{Resumo}

O objetivo deste trabalho foi determinar os valores de energia metabolizável aparente (EMA), os valores de EMA corrigida para o balanço de nitrogênio (EMAn), os coeficientes de metabolizabilidade aparente (CMA) da energia bruta e os CMA corrigidos para o balanço de nitrogênio (CMAn) de cinco diferentes alimentos de origem vegetal (milho, farelo de soja, soja integral desativada, farelo de trigo e óleo de soja) com frangos de corte em diferentes idades (1 a 8, 11 a 18, 21 a 28, 31 a 38 e 41 a 48 dias). Foi utilizado o método de coleta total de excretas. Os frangos foram distribuídos em um delineamento inteiramente casualizado, com cinco tratamentos e cinco repetições cada, totalizando 25 unidades experimentais. Os valores de EMA e EMAn aumentaram com a idade das aves para a maioria

\footnotetext{
${ }_{1}$ Pesquisa financiada pelo Conselho Nacional de Desenvolvimento Científico e Tecnológico, CNPq.

2 Mestres em Zootecnia, Programa de Pós-Graduação em Zootecnia, PPZ, Universidade Estadual do Oeste do Paraná, UNIOESTE, Marechal Cândido Rondon, PR, Brasil. E-mail: ze.luiz@zootecnista.com.br; rodrigoschone87@gmail.com; rafaelfrankrafael@ hotmail.com

3 Profs., Centro de Ciências Agrárias, UNIOESTE, Marechal Cândido Rondon, PR, Brasil. E-mail: nunesrv@hotmail.com; claudio.tsutsumi@unioeste.br

${ }^{4}$ Profs., Centro de Ciências Agrárias, Universidade Estadual de Maringá, UEM, Maringá, PR, Brasil. E-mail: thaislorana@ hotmail.com; leandrocastilha@hotmail.com

5 Pós-Doutora em Zootecnia, Programa de Pós-Graduação em Zootecnia, PPZ, UNIOESTE, Marechal Cândido Rondon, PR, Brasil. E-mail: carina_scherer@hotmail.com

* Author for correspondence
} 
dos alimentos, exceto para o farelo de soja. O menor CMA e CMAn da energia bruta foi obtido com o farelo de trigo. Houve ajuste das equações ao modelo LRP para o CMA do milho, farelo de soja e soja integral desativada. O farelo de trigo e o óleo de soja se ajustaram ao modelo de regressão linear. As equações demonstram que a metabolizabilidade da energia tende a aumentar com a idade, com exceção do farelo de soja, que teve maior metabolizabilidade com aves mais jovens. Conclui-se que a idade das aves influencia na determinação dos valores de energia metabolizável dos alimentos.

Palavras-chave: Alimentação. Avicultura. Coleta total. Energia metabolizável. Ensaio de metabolismo.

\section{Introduction}

The energy contained in food and feed for poultry can be measured in its crude form, digestible or metabolizable. Apparent metabolizable energy (AME) is the most commonly used in researches with broilers, since it is more easily measured in relation to digestible energy, because birds excrete feces and urine together.

There is, however, a frequently performed change in the AME values of food, which consists in the correction of its values according to the nitrogen balance of the animals (AMEn). In this regard, Leeson and Summers (2001) emphasize that it is impossible to determine that all the birds used in experimental trials have the same growth rate and, therefore, nitrogen correction is necessary.

Growing birds usually present higher AMEn values, due to the higher retention of nitrogen for deposition of protein tissue (GENEROSO et al., 2008). According to Nery et al. (2007), nitrogen retained as tissue, if catabolized, favors endogenous urinary energy losses, contributing to variations in AME values.

Several factors may affect the dry matter values. The main ones seem to be the composition of the food itself, the type and level of inclusion of the ingredients, calcium and phosphorus levels, antinutritional factors, feed intake, the methodology used to determine the AME and, not least, the age of the birds (SCOTTA et al., 2016).

Thus, the determination of metabolizable energy at different ages of birds becomes important, since the digestibility of the energy tends to increase with the age of birds, due to development of the digestive tract and the improvement of its capacity for nutrient and energy utilization by the birds as a function of increased secretion of bile salts and increased activity of the lipase enzyme, in addition to the more expressive fermentation of structural carbohydrates in the cecum (QUEIROZ et al., 2015).

According to Andrade et al. (2016), younger birds utilize less energy from food than older birds, especially in the case of vegetable ingredients. The penalization of metabolizable energy determination due to nitrogen balance correction is also more representative in younger birds.

The objective of this work was to determine the AME, the AMEn, the apparent coefficients of metabolization (ACM) of gross energy and the corrected ACM for nitrogen balance (ACMn) of five different foods of plant origin (maize, soybean meal, deactivated whole soybean, wheat bran and soybean oil) for broilers at different ages.

\section{Material and Methods}

The experiment was conducted at the Laboratory of Physiology and Experimental Station for Poultry Metabolism, State University of Paraná West UNIOESTE. All experimental procedures were previously submitted to the Animal Care and Use Committee of UNIOESTE, and were approved for execution (Protocol number 042/2012).

The AME and AMEn values of five different foods of plant origin used in feed for broiler chickens were determined: grain corn, soybean meal, deactivated whole soybean, wheat bran and soybean oil.

In order to determine the chemical composition of the foods, dry matter (DM), crude protein (CP), 
gross energy (GE), mineral matter (MM), mineral calcium $(\mathrm{Ca})$, phosphorus $(\mathrm{P})$, magnesium $(\mathrm{Mg})$, sodium $(\mathrm{Na})$ and potassium $(\mathrm{K})$ were analyzed according to Silva and Queiroz(2006). The geometric mean diameter (GMD) of the feed particles was determined according to the methodology proposed by Zanotto and Bellaver (1996).

The determinations of the AME and AMEn values of the foods were performed using the methodology of total excreta collection, described by Sakomura and Rostagno (2016), in broilers at different ages: 1 to 8 (phase 1 - pre-initial), 11 to 18 (phase 2 - initial), 21 to 28 (phase 3 - growth 1 ), 31 to 38 (phase 4 - growth 2) and 41 to 48 (phase 5 - termination) days of age, thereby totaling five metabolism assays.
In the pre-initial, initial, growth 1 , growth 2 and final (end) phases, 375, 250, 125, 100 and 100 male broilers of the Cobb 500 strain, respectively, were used. The birds were purchased from a known hatchery and received rations (initial and growth) and water ad libitum until reaching their respective ages.

Five reference rations (RRs), based on maize and soybean meal (Table 1), were calculated to meet the nutritional requirements of birds at different ages, according to the recommendations proposed by Rostagno et al. (2011). The tested foods replaced: 40 $\mathrm{kg} / 100 \mathrm{~kg}$ of RR for maize, $20 \mathrm{~kg} / 100 \mathrm{~kg}$ of RR for soybean meal, deactivated whole soybean and wheat bran, and $10 \mathrm{~kg} / 100 \mathrm{~kg}$ of RR for soy oil.

Table 1. Ingredients, chemical and energetic composition of reference-diets used in each phase.

\begin{tabular}{|c|c|c|c|c|c|}
\hline \multirow{2}{*}{ Ingredients } & \multicolumn{5}{|c|}{ Age (days) } \\
\hline & 1 to 8 & 11 to 18 & 21 to 28 & 31 to 38 & 41 to 48 \\
\hline Corn (kg) & 53.050 & 56.520 & 59.113 & 62.163 & 65.606 \\
\hline Soybean meal 45\% (kg) & 39.837 & 35.968 & 32.625 & 29.624 & 26.903 \\
\hline Soybean oil $(\mathrm{kg})$ & 2.677 & 3.478 & 4.501 & 4.661 & 4.018 \\
\hline Dicalcium phosphate $(\mathrm{kg})$ & 1.929 & 1.833 & 1.686 & 1.529 & 1.444 \\
\hline Limestone $(\mathrm{kg})$ & 0.932 & 0.903 & 0.854 & 0.809 & 0.787 \\
\hline Salt (kg) & 0.517 & 0.503 & 0.478 & 0.453 & 0.437 \\
\hline DL-methionine $(\mathrm{kg})$ & 0.357 & 0.263 & 0.238 & 0.225 & 0.220 \\
\hline L-lysine $\mathrm{HCl}(\mathrm{kg})$ & 0.302 & 0.196 & 0.183 & 0.207 & 0.245 \\
\hline L-threonine $(\mathrm{kg})$ & 0.120 & 0.057 & 0.043 & 0.049 & 0.062 \\
\hline Vitamin supplement $^{1}(\mathrm{~kg})$ & 0.100 & 0.100 & 0.100 & 0.100 & 0.100 \\
\hline Mineral supplement ${ }^{2}(\mathrm{~kg})$ & 0.050 & 0.050 & 0.043 & 0.050 & 0.050 \\
\hline Cholin chloride $60 \%(\mathrm{~kg})$ & 0.060 & 0.060 & 0.060 & 0.060 & 0.060 \\
\hline $\operatorname{Anticoccidial}^{3}(\mathrm{~kg})$ & 0.050 & 0.050 & 0.050 & 0.050 & 0.050 \\
\hline Growth $\operatorname{promoter}^{4}(\mathrm{~kg})$ & 0.010 & 0.010 & 0.010 & 0.010 & 0.010 \\
\hline Antioxidant $^{5}(\mathrm{~kg})$ & 0.010 & 0.010 & 0.010 & 0.010 & 0.010 \\
\hline Total & 100.00 & 100.00 & 100.00 & 100.00 & 100.00 \\
\hline \multicolumn{6}{|c|}{ Composition } \\
\hline Metabolizable energy (kcal/kg) & 2,960 & 3,050 & 3,150 & 3,200 & 3,200 \\
\hline Crude protein $(\mathrm{g} / \mathrm{kg})$ & 230.0 & 213.4 & 200.0 & 189.1 & 180.0 \\
\hline Calcium $(\mathrm{g} / \mathrm{kg})$ & 9.42 & 8.99 & 8.37 & 7.75 & 7.40 \\
\hline Available phosphorus (g/kg) & 4.71 & 4.49 & 4.18 & 3.86 & 3.68 \\
\hline Sodium $(g / k g)$ & 2.24 & 2.18 & 2.08 & 1.98 & 1.92 \\
\hline Potassium $(\mathrm{g} / \mathrm{kg})$ & 8.78 & 8.17 & 7.63 & 7.16 & 6.76 \\
\hline SID methionine $(\mathrm{g} / \mathrm{kg})$ & 6.67 & 5.57 & 5.18 & 4.92 & 4.77 \\
\hline SID met + cis $(g / k g)$ & 9.68 & 8.44 & 7.91 & 7.55 & 7.31 \\
\hline
\end{tabular}


continuation

\begin{tabular}{lccccc} 
SID lysine $(\mathrm{g} / \mathrm{kg})$ & 13.63 & 11.89 & 10.99 & 10.48 & 10.15 \\
SID isoleucine $(\mathrm{g} / \mathrm{kg})$ & 9.03 & 8.38 & 7.80 & 7.30 & 6.87 \\
SID leucine $(\mathrm{g} / \mathrm{kg})$ & 17.97 & 17.06 & 16.24 & 15.57 & 15.03 \\
SID valine $(\mathrm{g} / \mathrm{kg})$ & 9.55 & 8.92 & 8.37 & 7.89 & 7.49 \\
SID threonine $(\mathrm{g} / \mathrm{kg})$ & 8.86 & 7.73 & 7.14 & 6.81 & 6.60 \\
SID tryptophan $(\mathrm{g} / \mathrm{kg})$ & 2.55 & 2.35 & 2.18 & 2.03 & 1.90 \\
SID arginine $(\mathrm{g} / \mathrm{kg})$ & 14.66 & 13.54 & 12.57 & 11.72 & 10.97 \\
\hline
\end{tabular}

${ }^{1}$ Vitamin supplement - content/kg: vit. A - 9,000 UI; vit. D3 - 2,500 UI; vit. E - 20 UI; vit K3 - 2,500mg; vit. B1 - 1,500mg; vit. B2 - 6,000mg; vit. B6 - 3,000mg; vit. B12 - 12,000 mcg; Biotin - 60mg; Folic acid - 800mg; Nicotinic acid - 25,000mg; Pantothenic acid - 12,000mg; Selenium - 250mg; ${ }^{2}$ Mineral supplement: Manganese - 160mg; Iron - 100mg; Zinc - 100 mg; Cupper - 20mg; Cobalt - 2mg; Iodine - 2mg; ${ }^{3}$ Salinomicin; ${ }^{4}$ Avilamicin; ${ }^{5}$ B.H.T.

At the respective ages, the birds were transferred to the metabolism cages, distributed in a completely randomized design, with five treatments and five replicates, totaling 25 experimental units (EUs) for each experimental trial, which lasted 15 days, with ten for adaptation to the metabolism cages and to the test rations, and five days for the total collection of excreta, which was performed twice a day (SAKOMURA; ROSTAGNO, 2016), with an interval of 12 hours, to avoid possible fermentations, as recommended by Rodrigues et al. (2006).

The excreta collected throughout the experimental phase was stored in plastic bags, identified and stored in a freezer until the end of the collection period. Subsequently, it was thawed, weighed and homogenized, and samples were taken for laboratory analysis. Preheating was performed in a ventilated oven at $55^{\circ} \mathrm{C}$ for 72 hours. The samples were then ground and sent to the Laboratory of Animal Nutrition of UNIOESTE to perform the bromatological and mineral analyses. In the laboratory of the State University of Maringá (COMCAP / UEM), in Maringá (Paraná, Brazil), the values of gross energy (GE) were determined.

At the end of each test, the feed intake and the total amount of excreta per EU were measured and, based on the results of chemical composition analysis of the foods, diets and excreta, the AME and AMEn values were calculated using equations proposed by Matterson et al. (1965). After the determination of the metabolizable energy values, the ACM were calculated for each food in each studied phase, as well as the ACMn.

Analysis of variance (ANOVA) was performed as the statistical procedure, and a linear regression and/or linear response plateau (LRP) was carried out according to the best fit, considering $\mathrm{R}^{2}$, to verify the effects of different ages on the metabolizable coefficients of AME and AMEn values, for each food in the different periods. In the same period, ANOVA and Tukey's test were performed at a 0.05 probability level to verify which food has the best energy utilization within the same age, through the Statistical and Genetic Analysis System (SAEG) (UNIVERSIDADE FEDERAL DE VIÇOSA UFV, 2005).

\section{Results and Discussion}

The chemical composition of the foods obtained in the laboratory analyses, as dry matter (DM), crude protein (CP), gross energy (GE), ether extract (EE), mineral matter (MM), neutral detergent fiber (NDF), acid detergent fiber (ADF), calcium (Ca), phosphorus $(\mathrm{P})$, magnesium $(\mathrm{Mg})$, sodium $(\mathrm{Na})$, potassium $(\mathrm{K})$ and geometric mean diameter (GMD) presented variation (Table 2) in relation to values described in the current literature (ROSTAGNO et al., 2011; QUEIROZ et al., 2015; SCOTTA et al., 2016; ANDRADE et al., 2016) probably due to the very difference in the varieties of food evaluated, besides cultivars, crops, fertilization of the soil and forms of industrial processing. 
The laboratory analysis revealed that the value obtained for $\mathrm{CP}$ of corn was lower than that described by Carvalho et al. (2004), Rodrigues et al. (2001) and Rostagno et al. (2011), but higher than that cited by Nunes et al. (2008) and D'Agostini et al. (2004). The value of $\mathrm{EE}$ found for corn was similar to the value found by Nery et al. (2007), but lower than the EE value of Mello et al. (2009).

Table 2. Chemical composition of evaluated foods, as fed basis.

\begin{tabular}{lccccc}
\hline Composition & Corn & Soybean meal & Deactivated whole soybean & Wheat bran & Soybean oil \\
\hline $\mathrm{DM}(\mathrm{g} / \mathrm{kg})$ & 868.7 & 882.0 & 889.2 & 868.3 & 996.0 \\
$\mathrm{CP}(\mathrm{g} / \mathrm{kg})$ & 89.6 & 464.6 & 332.6 & 163.1 & - \\
$\mathrm{CE}(\mathrm{kcal} / \mathrm{kg})$ & 3955 & 4199 & 5317 & 4028 & 9341 \\
$\mathrm{EE}(\mathrm{g} / \mathrm{kg})$ & 31.3 & 17.4 & 154.9 & 26.3 & 996.0 \\
$\mathrm{MM}(\mathrm{g} / \mathrm{kg})$ & 10.7 & 60.5 & 47.0 & 48.8 & - \\
$\mathrm{NDF}(\mathrm{g} / \mathrm{kg})$ & 152.2 & 115.8 & 150.4 & 403.7 & - \\
$\mathrm{ADF}(\mathrm{g} / \mathrm{kg})$ & 33 & 65.9 & 91.2 & 114.2 & - \\
$\mathrm{Ca}(\mathrm{g} / \mathrm{kg})$ & 0.85 & 4.65 & 3.60 & 1.70 & - \\
$\mathrm{P}(\mathrm{g} / \mathrm{kg})$ & 2.20 & 6.30 & 6.30 & 11.10 & - \\
$\mathrm{Mg}(\mathrm{g} / \mathrm{kg})$ & 1.70 & 2.05 & 2.75 & 3.90 & - \\
$\mathrm{Na}(\mathrm{g} / \mathrm{kg})$ & 1.50 & 3.65 & 1.65 & 2.25 & - \\
$\mathrm{K}(\mathrm{g} / \mathrm{kg})$ & 2.90 & 22.30 & 18.25 & 11.90 & - \\
$\mathrm{GMD}(\mu \mathrm{m})$ & 751 & 563 & 1588 & 605 & - \\
\hline
\end{tabular}

*DM - Dry matter; CP - Crude protein; GE - Gross energy; EE - Ether extract; MM - Mineral matter; NDF - Neutral detergent fiber; ADF - Acid detergent fiber; Ca - Calcium; P - Phosphorus; Mg - Magnesium; Na - Sodum; K - Potassium; GMD Geometric mean diameter.

From the GMD analysis, soybean meal and corn were classified as being of fine grain size, while the deactivated whole soybean and wheat bran presented medium granulometry. It is important to relate the nutrient digestibility coefficients or the energy coefficients contained in the foods to their granulometry, since the particle size influences the retention time in the gastrointestinal tract (passage rate), as well as the action of enzymes and biliary juice on the chyme, which will result in different rates of nutrient utilization.

According to Zanotto and Bellaver (1996), the foods are classified as fine granulometry when they present a GMD lower than $0.60 \mathrm{~mm}$, average when the GMD varies from 0.60 to $2.00 \mathrm{~mm}$, and thick when the GMD is higher than $2.00 \mathrm{~mm}$.

Corn and soybean meal presented mean AMEn values lower than those published by Rostagno et al. (2011). From 11 to 18 days and 41 to 48 days (Table 3), the corn AMEn values were 2964.12 and
$3137.42 \mathrm{kcal} / \mathrm{kg}$, respectively, both lower than those presented by Mello et al. (2009) at similar ages.

The AMEn of the soybean meal, from 11 to 18 days of age, presented a value of $2299.96 \mathrm{kcal} / \mathrm{kg}$, higher than those determined by Mello et al. (2009) and by Calderano et al. (2010). In the period from 41 to 48 days, the AMEn of soybean meal was inferior to the value presented by the authors mentioned above.

The deactivated whole soybean presented, on average, $253 \mathrm{kcal} / \mathrm{kg}$ more than the values of AMEn determined by Calderano et al. (2010), at all ages. For wheat bran, AMEn values were higher than those obtained by Mello et al. (2009) in the periods from 11 to $18(1770.72 \mathrm{kcal} / \mathrm{kg})$ and from 41 to 48 days of age $(1973.85 \mathrm{kcal} / \mathrm{kg})$.

According to Queiroz et al. (2015), the increase in AMEn value with the advancement of the chicken's age is caused by the improvement in the 
use of the food nutrients. This may occur because the activity of the enzymes amylase, trypsin and lipase increases after birth, and the phase of increased activity occurs between the first and second week of life (SAKOMURA et al., 2004), which could be observed in the present experiment, in which the majority of foods showed an increase in AMEn from 11 days of age.

Table 3. AME and AMEn values of foods (as fed basis) determined for poultry in different ages.

\begin{tabular}{lccccc}
\hline & \multicolumn{5}{c}{ Age (days) } \\
\cline { 2 - 6 } Foods & 1 to 8 & 11 to 18 & 21 to 28 & 31 to 38 & 41 to 48 \\
\cline { 2 - 5 } & 2990.77 & 2996.58 & 3053.09 & 3132.69 & 3171.49 \\
\hline Corn & 2363.15 & 2345.95 & 2318.94 & 2177.38 & 2153.91 \\
Soybean meal & 3328.45 & 3507.69 & 3643.11 & 3642.48 & 4117.31 \\
Deactivated whole soybean & 1718.58 & 1672.59 & 1687.94 & 1868.08 & 2113.22 \\
Wheat bran & 8117.49 & 8039.31 & 8710.24 & 8675.93 & 9403.42 \\
Soybean oil & \multicolumn{5}{c}{ AMEn $(\mathrm{kcal} / \mathrm{kg})$} \\
\hline & 2797.60 & 2964.12 & 3006.47 & 3110.58 & 3137.42 \\
\hline Corn & 1942.57 & 2299.96 & 2084.83 & 2013.17 & 2008.79 \\
Soybean meal & 3026.66 & 3483.13 & 3433.76 & 3521.36 & 3950.04 \\
Deactivated whole soybean & 1585.80 & 1770.72 & 1621.48 & 1802.80 & 1973.85 \\
Wheat bran & 8024.20 & 8926.39 & 8641.57 & 8705.82 & 9298.71 \\
Soybean oil & \multicolumn{5}{c}{} \\
\hline
\end{tabular}

In order to determine the AME and AMEn of corn and soybean meal in rations for growing broilers, Lopez and Leeson (2008) worked with total excreta collection, using linear regression as an alternative method of calculating the values of significant linear regression for both maize and soybean meal. Even with a better fit for the corn equations, the AME and AMEn values were little affected by age, with a higher variation in the soybean meal values.

The results can be explained by the age of the birds that were submitted to the collection period. Lower values and energy coefficients are found in the pre-initial and initial phases. In the growth phase (the phase in which the experiment was performed), there is a greater activity of the enzymes responsible for the digestion of the food, which means that the energy values do not suffer much oscillation within this phase (SAKOMURA et al., 2004).

The older birds presented higher values of ACM and ACMn $(\mathrm{P}<0.05)$ for corn, deactivated whole soybean and wheat bran (Table 4 ). This result has probably been found in response to maturity in the enzymatic synthesis of the animals, since at younger ages birds still have limited ability to degrade nutrients or groups of more complex nutrients, such as nonstarch carbohydrates and lipids. In this respect, BRUMANO et al. (2006) mention that, from the end of the second week of life and the beginning of the third, due to the development of the digestive tract and the consequent increase in the production of enzymes, the birds increase the digestibility of the nutrients and the energy contained in the feed.

At the different ages evaluated, there was no difference $(\mathrm{P}>0.05)$ in the ACM and ACMn values for the same food. However, for all evaluated foods, with the exception of soybean meal, energy metabolizability increased linearly $(\mathrm{P}<0.05)$ as a function of the advancement of poultry age, with the lowest AMC obtained for wheat bran, probably as a response of the gastrointestinal tract to the fibrous content of this food, when compared to the others.

This corroborates the results presented by Mello et al. (2009), who evaluated foods such as corn, soybean meal, sorghum, wheat bran and whole rice 
bran. The authors suggest that this negative result for wheat bran is probably due to the high levels of NDF and ADF, and the high amounts of soluble nonstarch polysaccharides present in this food, which promote the increase of the viscosity of the digesta, impairing the digestibility of nutrients.

Table 4. Apparent coefficients of metabolization (ACM) of gross energy and ACM corrected for nitrogen balance (ACMn) of foods determined with broilers at different ages and between foods, compared for the same age.

\begin{tabular}{|c|c|c|c|c|c|c|c|}
\hline \multirow{3}{*}{ Foods } & \multicolumn{5}{|c|}{ Age (days) } & \multirow{3}{*}{ CV $(\%)$} & \multirow{3}{*}{ Effect } \\
\hline & 1 to 8 & 11 to 18 & 21 to 28 & 31 to 38 & 41 to 48 & & \\
\hline & \multicolumn{5}{|c|}{$\mathrm{ACM}(\%)$} & & \\
\hline Corn & $0.754^{\mathrm{b}}$ & $0.758^{\mathrm{b}}$ & $0.772^{\mathrm{b}}$ & $0.790^{\mathrm{b}}$ & $0.802^{\mathrm{c}}$ & 4.126 & Lin, LRP \\
\hline Soybean meal & $0.562^{\mathrm{d}}$ & $0.562^{\mathrm{d}}$ & $0.554^{\mathrm{d}}$ & $0.520^{\text {de }}$ & $0.514^{\mathrm{f}}$ & 6.726 & Lin, LRP \\
\hline Deactivated whole soybean & $0.626^{\mathrm{c}}$ & $0.662^{\mathrm{c}}$ & $0.686^{\mathrm{c}}$ & $0.684^{\mathrm{c}}$ & $0.774^{\mathrm{cd}}$ & 8.331 & Lin, LRP \\
\hline Wheat bran & $0.426^{\mathrm{e}}$ & $0.416^{\mathrm{e}}$ & $0.418^{\mathrm{e}}$ & $0.462^{\mathrm{e}}$ & $0.524^{\mathrm{f}}$ & 11.055 & Lin \\
\hline \multirow[t]{2}{*}{ Soybean oil } & $0.862^{\mathrm{a}}$ & $0.854^{\mathrm{a}}$ & $0.924^{\mathrm{a}}$ & $0.920^{\mathrm{a}}$ & $0.996^{\mathrm{a}}$ & 6.137 & Lin \\
\hline & \multicolumn{5}{|c|}{ ACMn $(\%)$} & & \\
\hline Corn & $0.706^{\mathrm{b}}$ & $0.748^{\mathrm{b}}$ & $0.760^{\mathrm{b}}$ & $0.786^{\mathrm{b}}$ & $0.794^{\mathrm{b}}$ & 5.488 & Lin \\
\hline Soybean meal & $0.462^{\mathrm{e}}$ & $0.540^{\mathrm{d}}$ & $0.498^{\mathrm{d}}$ & $0.480^{\text {de }}$ & $0.478^{\mathrm{e}}$ & 9.767 & NS \\
\hline Deactivated whole soybean & $0.568^{\mathrm{cd}}$ & $0.656^{\mathrm{c}}$ & $0.646^{\mathrm{c}}$ & $0.664^{\mathrm{c}}$ & $0.742^{\mathrm{b}}$ & 8.845 & Lin, LRP \\
\hline Wheat bran & $0.576^{\mathrm{cd}}$ & $0.680^{\mathrm{bc}}$ & $0.646^{\mathrm{c}}$ & $0.656^{\mathrm{c}}$ & $0.652^{\mathrm{c}}$ & 8.711 & NS \\
\hline Soybean oil & $0.854^{\mathrm{a}}$ & $0.930^{\mathrm{a}}$ & $0.916^{\mathrm{a}}$ & $0.932^{\mathrm{a}}$ & $0.988^{\mathrm{a}}$ & 5.231 & Lin \\
\hline
\end{tabular}

*Means followed by the same capital letter in the line do not differ from each other by the Tukey test $(\mathrm{P}<0.05)$.

*Means followed by the same lowercase letter in the column do not differ from each other by the Tukey test $(\mathrm{P}<0.05)$.

The AMC of crude energy contained in corn, soybean meal and deactivated whole soybean presented a significant effect $(\mathrm{P}<0.05)$ and was better adjusted to the LRP model (Table 5). The equations show that for the corn ACM and deactivated whole soybean, as well as the ACMn of deactivated whole soybean, the energy metabolizability of these foods tends to increase with the advancement of the bird's age. However, although there was a significant effect and adjustment to this model for the ACMn of deactivated whole soybean, the LRP model was not the best fit for this variable.

Table 5. Equações ajustadas ao modelo linear response plateau (LRP).

\begin{tabular}{lcccccc}
\hline Feed & ACM & $\mathrm{R}^{2}$ & Plateau & ACMn & $\mathrm{R}^{2}$ & Plateau \\
\hline Corn & $74.5320+0.111^{*}$ AGE & 0.90 & 79.50 & - & - & - \\
Soybean meal & $57.4920-0.134 *$ AGE & 0.62 & 51.70 & - & - & - \\
Deactivated whole soybean & $61.6000+0.30 *$ AGE & 0.97 & 72.90 & $56.8733+0.39 *$ AGE & 0.31 & 70.30 \\
\hline
\end{tabular}

AMC: Apparent metabolizability coefficient; $\mathrm{R}^{2}$ : Determination coefficient; AMCn: AMC corrected for nitrogen balance.

However, the ACM equation for soybean meal demonstrates that the metabolizable energy for this food is higher in the first days of a bird's life, in contrast to that obtained for corn and deactivated whole soybean. According to Queiroz et al. (2015), the digestive capacity of birds in the early stages is not fully developed, because of the low activity of enzymes responsible for food digestion. Therefore, this result obtained for soybean meal in the early stages was not expected.

Leslie et al. (2007) conducted an experiment with broilers at different ages to determine the effect of phytase and B-glucanase on the energy values of corn and soybean meal. The authors found that in 
the early days of the birds there was no effect of the enzymes on ileal digestible energy. However, as age increased, there was also an increase in metabolizable energy for corn and soybean meal. The results found for corn corroborate the findings in the present study; however, for soybean meal there was a greater metabolizability of energy with younger birds, differing from the results found by these authors.

The equations for corn (ACM and ACMn), soybean meal (ACM), deactivated whole soybean (ACM and ACMn), wheat bran (ACM and ACMn) and soybean oil (ACM and ACMn) were significant $(\mathrm{P}<0.05)$ and adjusted to the linear regression model (Table 6).

Table 6. Equations adjusted to the linear regression model.

\begin{tabular}{lcccc}
\hline Feed & ACM & $\mathrm{R}^{2}$ & ACMn & $\mathrm{R}^{2}$ \\
\hline Corn & $75.5748+0.125804 *$ AGE & 0.30 & $70.9204+0.208869 *$ AGE & 0.53 \\
Soybean meal & $57.4588-0.139800^{*}$ AGE & 0.27 & - & - \\
Deactivated whole soybean & $60.8822+0.322115^{*}$ AGE & 0.67 & $57.0035+0.354554^{*}$ AGE & 0.67 \\
Wheat bran & $39.1244+0.244513 *$ AGE & 0.51 & $38.6584+0.200665 *$ AGE & 0.39 \\
Soybean oil & $82.9751+0.347472 *$ AGE & 0.73 & $86.5965+0.247087 *$ AGE & 0.52 \\
\hline
\end{tabular}

The ACM equations for maize, soybean meal and deactivated whole soybean did not adjust properly to the linear regression model, which obtained a better $\mathrm{R}^{2}(0.90,0.62$ and 0.97$)$ when adjusted to the model of LRP. The opposite can be observed for the ACMn equation of the deactivated whole soybean, in which there was adjustment for both the linear regression model and the LRP. However, in this case, there was a better fit to the linear regression model $\left(\mathrm{R}^{2}=0.67\right)$ when compared to the LRP $\left(\mathrm{R}^{2}=0.31\right)$. There was no effect $(\mathrm{P}>0.05)$ and there was no adjustment of the equations to any regression model for the ACMn of the crude energy contained in the soybean meal.

In the linear regression model, the equations show that for all foods in which there were significant differences, the metabolizable energy tends to increase with the age of the birds, with the exception of soybean meal, where younger birds take better advantage of the energy of that food than older birds.

The results found in this work for corn and wheat bran are in agreement with the results found by Mello et al. (2009), who performed four metabolism tests with three different ages of broilers (10 to 17, 26 to 33 and 40 to 47 days of age) and with cecectomized roosters.
The authors were able to verify that with the increase of the birds' ages, there was also an increase in the energy values, thereby increasing their coefficients of metabolizability for the different foods. In this study, in addition to the foods mentioned, rice bran, viscera flour, sorghum, feather meal, blood plasma and soybean meal were also evaluated. For all foods, there was an increase in the coefficients with the increase of the birds' ages, which differs from the results obtained for the soybean meal, where the metabolizability was higher in the first days of life.

\section{Conclusion}

For all evaluated foods, with the exception of soybean meal, the energy metabolizability tends to increase as the age of the birds increases. The lowest AMC were obtained for wheat bran.

\section{Acknowledgments}

This work was supported by grants from the National Council for Scientific and Technological Development (Conselho Nacional de Desenvolvimento Científico e Tecnológico-CNPq). 


\section{References}

ANDRADE, R. C.; LARA, L. J. C.; POMPEU, M. A.; CARDEAL, P. C.; MIRANDA, D. J. A.; BAIÃO, N. C. Avaliação da correção da energia pelo balanço de nitrogênio em alimentos para frangos de corte. Arquivo Brasileiro de Medicina Veterinária e Zootecnia, Belo Horizonte, v. 68, n. 2, p. 497-505, 2016.

BRUMANO, G.; GOMES, P. C.; ALBINO, L. F. T.; ROSTAGNO, H. S.; GENEROSO, R. A. R.; SCHIMIDT, M. Composição química e valores de energia metabolizável de alimentos proteicos determinados com frangos de corte em diferentes idades. Revista Brasileira de Zootecnia, Viçosa, MG, v. 35, n. 6, p. 2297-2302, 2006.

CALDERANO, A. A.; GOMES, P. C.; ALBINO, L. F. T.; ROSTAGNO, H. S.; SOUZA, R. M. D.; MELLO, H. H. D. C. Chemical and energetic composition of feedstuffs of plant origin for poultry at different ages. Revista Brasileira de Zootecnia, Viçosa, MG, v. 39, n. 2, p. 320326, 2010.

CARVALHO, D. C. O.; ALBINO, L. F. T.; ROSTAGNO, H. S.; OLIVEIRA, J. E.; VARGAS JUNIOR, J. G.; TOLEDO, R. S.; COSTA, C. H. R.; PINHEIRO, S. R. F.; SOUZA, R. M. Composição química e energética de amostras de milho submetidas a diferentes temperaturas de secagem e períodos de armazenamento. Revista Brasileira de Zootecnia, Viçosa, MG, v. 33, n. 2, p. 358364, 2004.

D'Agostini, P.; GOMeS, P. C.; ALBINO, L. F. T. Valores de composição química e energética de alguns alimentos para aves. Revista Brasileira de Zootecnia, Viçosa, MG, v. 33, n. 1, p. 128-134,2004.

GENEROSO, R. A. R.; GOMES, P. C.; ROSTAGNO, H. S.; ALBINO, L. F. T.; BARRETO, S. L. D. T.; BRUMANO, G. Chemical and energy composition of some feeds for broiler chicks and two ages. Revista Brasileira de Zootecnia, Viçosa, MG, v. 37, n. 7, p. 12511256, 2008.

LEESON, S.; SUMMERS, J. D. Minerals. In: Nutrition of the chicken. 4. ed. Guelph, Ontario: University Books, 2001. p. 394-397.

LESLIE, M. A.; MORAN, E. T.; BEDFORD, M. R. The effect of phytase and glucanase on the ileal digestible energy of corn and soybean meal fed to broilers. Poultry Science, Guelph, v. 86, n. 11, p. 2350-2357, 2007.

LOPEZ, G.; LEESON, S. Assessment of the nitrogen correction factor in evaluating metabolizable energy of corn and soybean meal in diets for broilers. Poultry Science, Guelph, v. 87, n. 2, p. 298-306, 2008.
MATTERSON, L. D.; POTTER, L. M.; STUTZ, M. W.; SINGSEN, E. P. The metabolizable energy of feed ingredients for chickens. University of Connecticut, Agricultural Experiment Station, Research Report, Storrs, Connecticut, v. 7, n. 1, p. 11-14, 1965.

MELLO, H. H. C.; GOMES, P. C.; ROSTAGNO, H. S.; ALBINO, L. F. T.; SOUZA, R. M.; CALDERANO, A. A. Valores de energia metabolizável de alguns alimentos obtidos com aves de diferentes idades. Revista Brasileira de Zootecnia, Viçosa, MG, v. 38, n. 5, p. 863-868, 2009.

NERY, L. R.; ALBINO, L. F. T.; ROSTAGNO, H. S.; CAMPOS, A. M. A.; SILVA, C. R. Valores de energia metabolizável de alimentos determinados com frangos de corte. Revista Brasileira de Zootecnia, Viçosa, MG, v. 36, n. 5, p. 1354-1358, 2007.

NUNES, R. V.; POZZA, P. C.; POTENÇA, A.; NUNIES, C. G. V.; POZZA. M. S. S.; LORENÇON, L.; EYNG, C.; NAVARINI, F. C. Composição química e valores energéticos do milho e da silagem de grãos úmidos de milho para aves. Revista Brasileira de Saúde e Produção Animal, Salvador, BA, v. 9, n. 1, p. 82-90, 2008.

QUEIROZ, A. P. L. B. de; CARVALHO, C. M. C.; MARTINS, J. M. D. S.; LITZ, F. H.; FERNANDES, E. D. A. Composição bromatológica, energia metabolizável e digestibilidade de nitrogênio e extrato etéreo de amostras de milho e sorgo para frangos de corte em diferentes idades. Veterinária Notícias, Uberlândia, v. 21, n. 1, p. 30-40, 2015.

RODRIGUES, P. B.; MARTINEZ, R. S.; FREITAS, R. T. F.; BERTECHINI, A. G.; FIALHO, E. T. Influência do tempo de coleta e metodologias sobre a digestibilidade e o valor energético de rações para aves. Revista Brasileira de Zootecnia, Viçosa, MG, v. 34, n. 3, p. 882-889, 2005.

RODRIGUES, P. B.; ROSTAGNO, H. S.; ALBINO, L. F. T.; GOMES, P. C.; BARBOZA, W. A.; SANTANA, R. T. Valores energéticos do milheto, do milho e subprodutos do milho, determinados com frangos de corte e galos adultos. Revista Brasileira de Zootecnia, Viçosa, MG, v. 30, n. 6, p. 1767-1778, 2001.

ROSTAGNO, H. S.; ALBINO, L. F. T.; DONZELE, J. L.; GOMES, P. C.; OLIVEIRA, R. F. M.; LOPES, D. C.; FERREIRA, A. S.; BARRETO, S. L. T.; EUCLIDES, R. F. Tabelas brasileiras para aves e suinos: composição de alimentos e exigências nutricionais. 3. ed. Viçosa, MG: Universidade Federal de Viçosa, 2011. 252 p.

SAKOMURA, N. K.; BIANCHI, M. D.; PIZAURO, J. M.; FREITAS, E. R. Efeito da idade dos frangos de corte sobre a atividade enzimática e digestibilidade dos nutrientes do farelo de soja e da soja integral. Revista Brasileira de Zootecnia, Viçosa, MG, v. 33, n. 4, p. 924935, 2004. 
SAKOMURA, N. K.; ROSTAGNO, H. S. Métodos de pesquisa em nutrição de monogástricos. 2. ed. Jaboticabal: Funep, 2016. 262 p.

SCOTTA, B. A.; ALBINO, L. F. T.; BRUSTOLINI, P. C.; GOMIDE, A. P. C.; CAMPOS, P. F.; RODRIGUES, V. V. Determinação da composição química e dos valores de energia metabolizável de alguns alimentos proteicos para frangos de corte. Ciência Animal Brasileira, Goiânia, v. 17, n. 4, p. 501-508, 2016.
SILVA, D. J.; QUEIROZ, A. C. Análise de alimentos: métodos químicos e biológicos. 3. ed. Viçosa, MG: UFV, 2006. $275 \mathrm{p}$.

UNIVERSIDADE FEDERAL DE VIÇOSA - UFV. Central de processamento de dados - UFV/CPD. SAEG - Sistema para análises estatísticas. Versão 9. 1. Viçosa, MG: UFV, 2005. 301 p.

ZANOTTO, D. L.; BELLAVER, C. Método de determinação da granulometria de ingredientes para uso em rações de suínos e aves. Concórdia: EMBRAPA Suínos e Aves, 1996. 5 p. (Comunicado técnico, 215). 